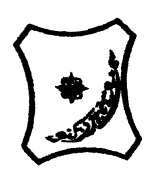

Bayero Journal of Pure and Applied Sciences, 12(1): 40 - 51

Received: April, 2018

Accepted: December, 2018

ISSN $2006-6996$

\title{
COMPARATIVE STUDY OF NUTRITIONAL CONTENTS OF Ocimum basilicum AND Ocimum gratissimum PLANT LEAVES AND SOIL SAMPLES FROM BORNO AND ENUGU STATES, NIGERIA
}

\author{
Anjili, E. M., Nuhu A. A. and Uba, S. \\ Department of Chemistry Ahmadu Bello University Zaria Kaduna State, Nigeria. \\ *Correspondence author:ezekielanjili@gmail.com; 08067937341
}

ABSTRACT

0 . basilicum and 0 . gratissimum leaves are one of the important nutritious and medicinal plants used in Nigeria and other parts of the world. The aim of this work was to determine the nutritional contents of 0 . basilicum and 0 . gratissimum leaves with its associated soil. The elemental analysis for leaves showed that Ca $(33024.60 \mathrm{mg} / \mathrm{kg}), \mathrm{Cu}$ $(28.50 \mathrm{mg} / \mathrm{kg}), K(2350.00 \mathrm{mg} / \mathrm{kg}), \mathrm{Zn}(98.80 \mathrm{mg} / \mathrm{kg})$ and $S(5091.33 \mathrm{mg} / \mathrm{kg})$, were highest in leaves found in Awgu town, while Fe $(2940.00 \mathrm{mg} / \mathrm{kg})$ and $P(4123.24 \mathrm{mg} / \mathrm{kg})$ were highest in leaves found in Nsukka town. Mn (101.60 $\mathrm{mg} / \mathrm{kg})$ in leaves found at $G$. R. A Damboa Road and N (34.05 mg/kg) in leaves found at 707 Housing Estate were highest in 0 . basilicum leaves found at Maiduguri. Cobalt was not detected in both 0 . basilicumand 0 . gratissimum leaves. The soils where both 0 . basilicumand 0 . gratissimum were planted were analyzed and showed that Ca $(7911.20 \mathrm{mg} / \mathrm{kg})$ and $\mathrm{K}$ (490.00 mg/kg) in 707Housing Estate samples were the highest and Co $(2.40 \mathrm{mg} / \mathrm{kg}), \mathrm{Cu}$ $(18.30 \mathrm{mg} / \mathrm{kg}), F e(35480.20 \mathrm{mg} / \mathrm{kg}), M n(338.60 \mathrm{mg} / \mathrm{kg}), \mathrm{Zn}(211.20 \mathrm{mg} / \mathrm{kg})$ and $P$ $(1012.72 \mathrm{mg} / \mathrm{kg})$ in Nsukka town samples were the highest; $S(1988.23 \mathrm{mg} / \mathrm{kg})$ and $\mathrm{N}$ (2.27 $\mathrm{mg} / \mathrm{kg})$ in Awgu town samples were the highest in soil. Both the leaves and soil were not toxic or contaminated compared with WHO/FAO standard for vegetable and soil and NAFDAC standard for food in the elemental concentration except with Fe. The proximate analysis showed that highest Carbohydrate content (31.58\%) and ash content (15.33\%) were found at 707 Housing Estate; highest moisture content (26.66\%), crude fiber (32.0\%), and crude fat (18.66\%) were found at G.R.A Damboa road while highest protein content $(7.61 \%)$, was found in 0 . gratissimum leaves at Nsukka town. The pH of 0 . basilicum leaves was slightly acid while that of 0 . gratissimum leaves was slightly basic. Both leaves showed good nutrition content with respect to the elemental composition, and proximate contents. Statistically both leaves showed no differences in all the content checked in respect to the nutritional contents.

Keywords: Elemental composition, 0 . basilicum and 0 . gratissimum leaves, Proximate contents and Soil.

\section{INTRODUCTION}

Nutrient is the basic substance that provides nourishment for the maintenance and sustenance of life and for growth. "Macronutrients are needed in larger quantities for the metabolic system to function; whilst micronutrients are needed in very small amounts which provide the necessary co-factors for metabolism to be carried out"(Clementson, 2014). Minerals such as calcium, potassium, sodium, phosphorus, magnesium, zinc, iron, and copper are confirmation of nutritional values (Bolanle et al., 2014).

Ocimum (Scent) leaf is an important nutritious plants commonly used in Nigeria and other parts of the world. In the northern part of Nigeria the leaf is called "Daidoya" by the Hausas while in the southern part of Nigeria it is called "Nchonwn" by the Igbo (Effrain et al., 2000).Scent leaves contain nutrients such as protein, carbohydrate, fat, vitamin, and mineral elements which are very useful to the human body (Katarzyna, 2010). Soil is the major source of nutrients in plant and soil nutrient can be affected by environmental factors. The wide consumption of scent leaves by Nigerians necessitates the determination of the quality of the two species of the Ocimum leaves in terms of their elemental composition and proximate content to know the different constituents which might affect human health. Also the quality of the soil on which the Ocimum plants are grown can affect the quality of their leaves. 
BAJOPAS Volume 12 Number 1, June, 2019

MATERIALS AND METHODS

Collection, identification and preparation of plants and soil samples

Fresh samples of Ocimum basilicum leaves and soil were collected from Government Residential Area along Damboa road, and 707 housing Estate at Maiduguri town, Borno state in NorthEastern Nigeria and Ocimum gratissimum plant leaves and soil were collected at Nsukka and Awgu towns Enugu town in South-Eastern part of Nigeria. Both leaves were examined and authenticated at the herbarium laboratory in the Department of Biological Science Ahmadu Bello University Zaria. The voucher number; 1285 for Ocimum gratissimum and 044 for Ocimum basilicum were given to the plants. The soil was collected at each sampling location using clean hand trowel by piercing the soil to $10 \mathrm{~cm}$ from the top soil within the garden. Fresh samples of scent leaves was washed with distilled water and dried at room temperature separately for 3 days. The two samples were then crushed in a mortar separately; the resulting powder was sieved, weighed and stored in black polyethene leather for further analysis. Likewise soil collected in three places at each sampling location was air dried at room temperature for 3 days then sieved and stored in a polythene leather for all the four sampling sites for further analyses.

\section{Mineral elements composition (determination)}

The mineral composition were determined by the Aqua regia method digesting both leaves and soil sample in a mixture of $6 \mathrm{~cm}{ }^{3}$ nitric acid and $6 \mathrm{~cm}^{3}$ hydrochloric acid (1:2) for metals. Ca, $\mathrm{Cu}, \mathrm{Co}, \mathrm{Fe}, \mathrm{Fe}, \mathrm{Mn}$ and $\mathrm{Zn}$ were determined using 280FS AA Model Atomic absorption spectroscopy adopting standard method (Saeid, 2012). $P$ and $S$ were determined using Carry 300 model UV-Vis spectroscopy and $\mathrm{N}$ was determined using Kjeldhl nitrogen method (AOAC, 1990). Exactly $1 \mathrm{~g}$ of each of the sample was used in both analyses.

\section{Proximate analysis}

The proximate contents of Ocimum basilicum and Ocimum gratissimum leaves were determined by following the official method of analysis. Exactly $1.5 \mathrm{~g}$ of each of both samples was carried out for each of the analysis. The moisture and crude fiber were determined (Owoso and Ogunmoyela, 2001). Crude protein, fats, $\mathrm{pH}$ and carbohydrate contents were determined (Gul and Mahpara, 2009) and ash contents was determined (Udo and Ogunwele, 1986). Exactly $1.5 \mathrm{~g}$ of samples was used in the analysis and all the proximate values were reported in percentages.
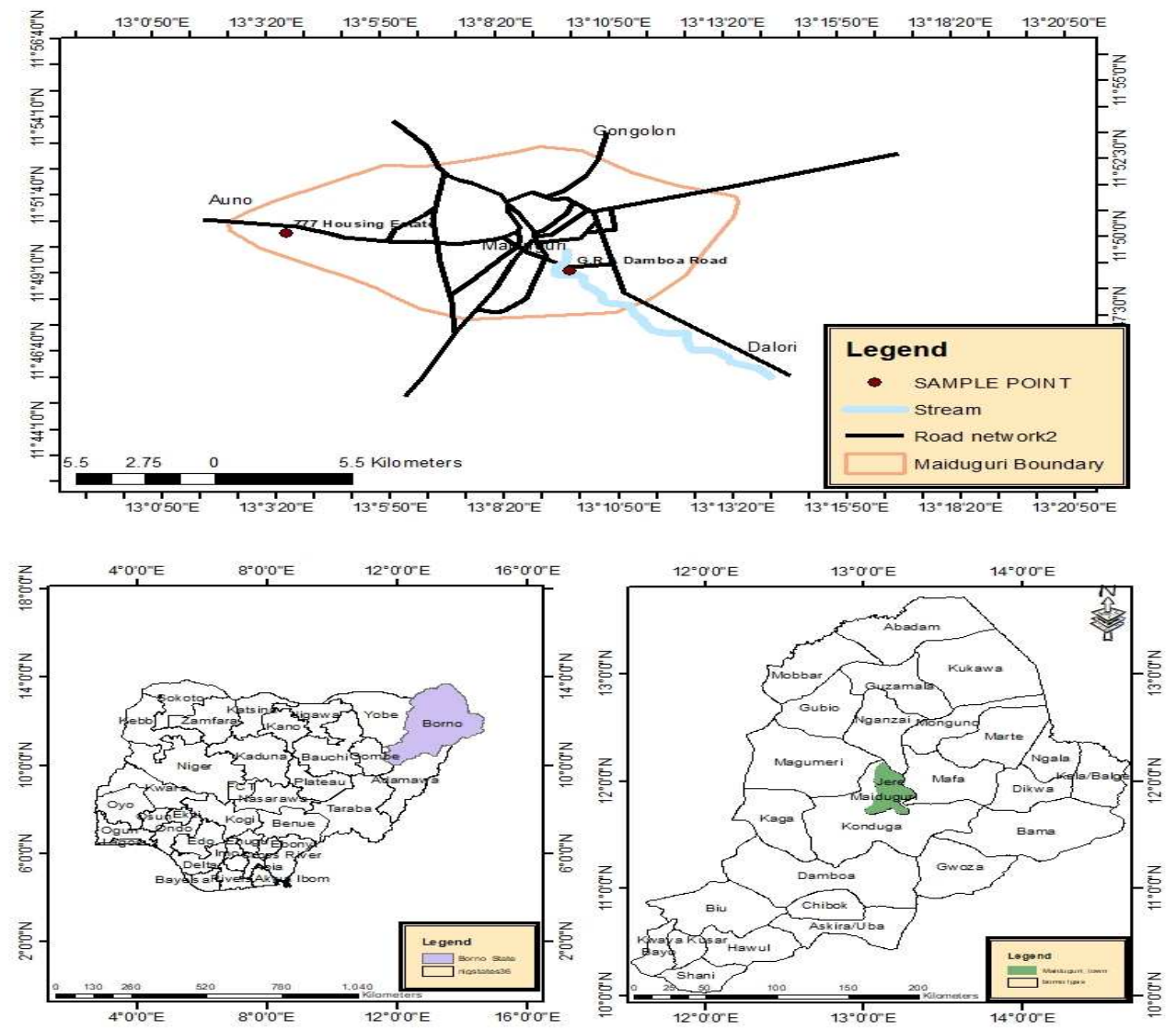

Figure 1: Map of Maiduguri town, Borno state, showing the sampling site. 
BAJOPAS Volume 12 Number 1, June, 2019
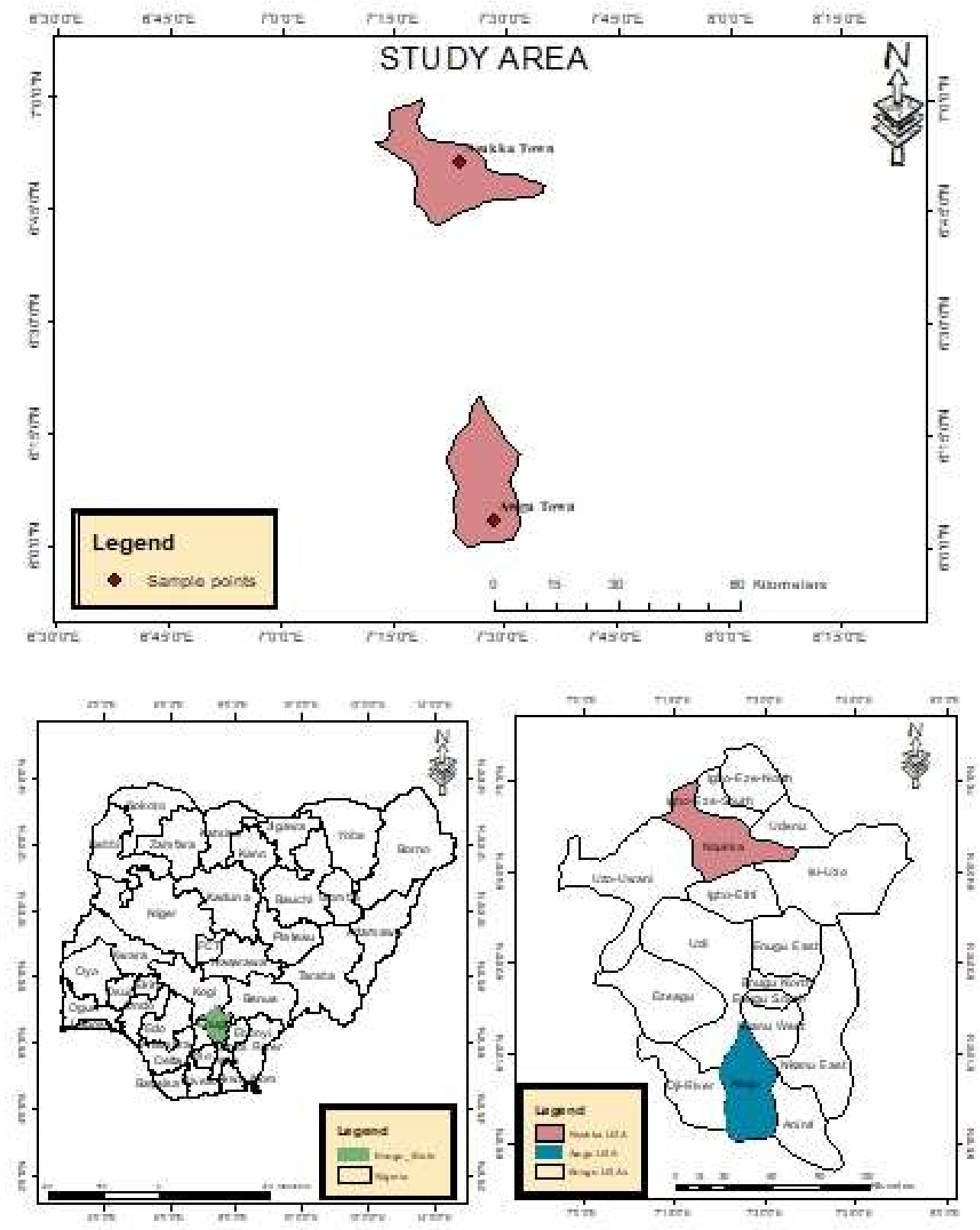

Figure 2: Map of Enugu town, Enugu state, showing the sampling site.

\section{Statistical analysis}

All results were presented as mean \pm standard deviation, the mean data of elemental analysis and proximate analysis of Ocimum basilicum and Ocimum gratissimum plant leaves with soil was done using special package for social science software (SPSS) version 16. 
BAJOPAS Volume 12 Number 1, June, 2019

RESULTS AND DISCUSSION

Table 1: $\quad$ Mean concentration \pm STD of metals concentration of Ocimumbasilicum and Ocimumgratissimumplant leaves.

\begin{tabular}{|c|c|c|c|c|c|c|}
\hline METAL & 707HEMOB & GRADMOB & NTEOG & ATEOG & $\begin{array}{c}\text { FAO/WHO } \\
\text { STD }\end{array}$ & $\begin{array}{c}\text { NAFDAC } \\
\text { STD }\end{array}$ \\
\hline $\begin{array}{l}\text { Ca }(\mathrm{mg} / \mathrm{kg}) \\
\mathrm{R}^{2}=0.998\end{array}$ & $\begin{array}{c}17089.90 \\
\pm \\
94.89\end{array}$ & $\begin{array}{c}19160.00 \\
\pm \\
26.85\end{array}$ & $\begin{array}{c}14096.00 \\
\pm \\
133.22\end{array}$ & $\begin{array}{c}33024.60 \\
\pm \\
477.19\end{array}$ & - & - \\
\hline $\begin{array}{l}\mathrm{Cu}(\mathrm{mg} / \mathrm{kg}) \\
\mathrm{R}^{2}=0.998\end{array}$ & $\begin{array}{c}5.10 \\
\pm \\
0.09\end{array}$ & $\begin{array}{c}12.30 \\
\pm \\
0.22\end{array}$ & $\begin{array}{c}18.30 \\
\pm \\
1.84\end{array}$ & $\begin{array}{c}28.50 \\
\pm \\
0.31\end{array}$ & 73.00 & $0-40.00$ \\
\hline $\begin{array}{l}\text { Co }(\mathrm{mg} / \mathrm{kg}) \\
\mathrm{R}^{2}=1.0\end{array}$ & ND & ND & ND & ND & 50.00 & $0-3.50$ \\
\hline $\begin{array}{l}\mathrm{Fe}(\mathrm{mg} / \mathrm{kg}) \\
\mathrm{R}^{2}=0.996\end{array}$ & $\begin{array}{c}526.00 \\
\pm \\
34.12\end{array}$ & $\begin{array}{c}1797.30 \\
\pm \\
12.95\end{array}$ & $\begin{array}{c}2940.00 \\
\pm \\
28.94\end{array}$ & $\begin{array}{c}973.70 \\
\pm \\
12.52\end{array}$ & 425.00 & $10-40.70$ \\
\hline $\begin{array}{l}\mathrm{K}(\mathrm{mg} / \mathrm{kg}) \\
\mathrm{R}^{2}=0.999\end{array}$ & $\begin{array}{c}1497.50 \\
\pm \\
85.20\end{array}$ & $\begin{array}{c}1795.00 \\
\pm \\
43.13\end{array}$ & $\begin{array}{c}1400.00 \\
\pm \\
113.13\end{array}$ & $\begin{array}{c}2350.00 \\
\pm \\
212.13\end{array}$ & - & - \\
\hline $\begin{array}{l}\mathrm{Mn}(\mathrm{mg} / \mathrm{kg}) \\
\mathrm{R}^{2}=0.998\end{array}$ & $\begin{array}{c}54.00 \\
\pm \\
0.56\end{array}$ & $\begin{array}{c}101.60 \\
\pm \\
0.41\end{array}$ & $\begin{array}{c}84.80 \\
\pm \\
4.00\end{array}$ & $\begin{array}{c}71.10 \\
\pm \\
0.60\end{array}$ & 500.00 & - \\
\hline $\begin{array}{l}\mathrm{Zn}(\mathrm{mg} / \mathrm{kg}) \\
\mathrm{R}^{2}=0.999\end{array}$ & $\begin{array}{c}37.30 \\
\pm \\
1.43\end{array}$ & $\begin{array}{c}59.10 \\
\pm \\
1.52\end{array}$ & $\begin{array}{c}88.20 \\
\pm \\
0.00\end{array}$ & $\begin{array}{c}98.80 \\
\pm \\
1.10\end{array}$ & 100.00 & $0-50.00$ \\
\hline
\end{tabular}

Key: 707HEMOB $=707$ Housing Estate MaiduguriOcimumbasilicum, GRADMOB = G.R.A Damboa Road MaiduguriOcimumbasilicum, NTEOG = Nsukka Town EnuguOcimumgratissimum, ATEOG = Awgu TownEnugu Ocimumgratissimum, FAO/WHO STD = Food and Agricultural Organization/ World Health Organization standard in Vegetable Maximum Permissible limit, NAFDAC STD = National Agency for Food and Drug Administration and Control In Food Maximum Permissible limit, ND = Not Detected.

Table 2: Mean concentration \pm STD of non-metals concentration of Ocimum basilicum and Ocimumgratissimum plant leaves.

\begin{tabular}{lcccc}
\hline & & & & \\
Non metals & 707HEMOB & GRADMOB & NTEOG & ATEOG \\
\hline $\mathrm{P}(\mathrm{mg} / \mathrm{kg})$ & 3580.66 & 3219.02 & 4123.24 & 1530.49 \\
& \pm & \pm & \pm & \pm \\
$\mathrm{S}(\mathrm{mg} / \mathrm{kg})$ & 51.21 & 17.05 & 102.30 & 72.14 \\
& 2351.00 & 2057.15 & 3467.72 & 5091.33 \\
& \pm & \pm & \pm & \pm \\
$\mathrm{N}(\mathrm{mg} / \mathrm{kg})$ & 332.48 & 83.15 & 83.12 & 202.34 \\
& 34.05 & 6.75 & 29.10 & 12.42 \\
& \pm & \pm & \pm & \pm \\
& 1.06 & 0.35 & 1.55 & 0.24 \\
\hline
\end{tabular}

Key: 707HEMOB $=707$ Housing Estate Maiduguri Ocimumbasilicum, GRADMOB = G.R.A Damboa Road Maiduguri Ocimumbasilicum, NTEOG = Nsukka Town Enugu Ocimumgratissimum, ATEOG = Awgu Town Enugu Ocimumgratissimum, 
BAJOPAS Volume 12 Number 1, June, 2019

Table 3: Mean concentration \pm STD of Metal concentration in soil were Ocimum basilicum and Ocimumgratissimumplants are planted compared with FAO/WHO STD.

\begin{tabular}{|c|c|c|c|c|c|}
\hline Metals & 707HEMSS & GRADMSS & NTESS & ATESS & $\begin{array}{l}\mathrm{FAO} / \mathrm{WHO} \\
\text { STD in soil }\end{array}$ \\
\hline $\begin{array}{l}\mathrm{Ca}(\mathrm{mg} / \mathrm{kg}) \\
\mathrm{R}^{2}=0.998\end{array}$ & $\begin{array}{c}7911.20 \\
\pm \\
24.91\end{array}$ & $\begin{array}{c}4568.60 \\
\pm \\
23.15\end{array}$ & $\begin{array}{c}1503.50 \\
\pm \\
8.71\end{array}$ & $\begin{array}{c}2779.00 \\
\pm \\
66.19\end{array}$ & - \\
\hline $\begin{array}{l}\mathrm{Cu}(\mathrm{mg} / \mathrm{kg}) \\
\mathrm{R}^{2}=0.998\end{array}$ & $\begin{array}{c}9.30 \\
\pm \\
0.94\end{array}$ & $\begin{array}{c}7.00 \\
\pm \\
0.04\end{array}$ & $\begin{array}{c}18.30 \\
\pm \\
0.89\end{array}$ & $\begin{array}{c}34.00 \\
\pm \\
0.31\end{array}$ & 100.00 \\
\hline $\begin{array}{l}\text { Co }(\mathrm{mg} / \mathrm{kg}) \\
\mathrm{R}^{2}=1.0\end{array}$ & ND & ND & $\begin{array}{c}2.40 \\
\pm \\
0.34\end{array}$ & ND & 50.00 \\
\hline $\begin{array}{l}\mathrm{Fe}(\mathrm{mg} / \mathrm{kg}) \\
\mathrm{R}^{2}=0.996\end{array}$ & $\begin{array}{c}2866.10 \\
\pm \\
197.58\end{array}$ & $\begin{array}{c}5745.00 \\
\pm \\
64.47\end{array}$ & $\begin{array}{c}35480.20 \\
\pm \\
481.33\end{array}$ & $\begin{array}{c}22016.70 \\
\pm \\
108.71\end{array}$ & 5000.00 \\
\hline $\begin{array}{l}\mathrm{K}(\mathrm{mg} / \mathrm{kg}) \\
\mathrm{R}^{2}=0.999\end{array}$ & $\begin{array}{c}4900.00 \\
\pm \\
29.69\end{array}$ & $\begin{array}{c}3407.50 \\
\pm \\
14.03\end{array}$ & $\begin{array}{c}2370.00 \\
\pm \\
15.98\end{array}$ & $\begin{array}{c}610.00 \\
\pm \\
18.38\end{array}$ & - \\
\hline $\begin{array}{l}\mathrm{Mn}(\mathrm{mg} / \mathrm{kg}) \\
\mathrm{R}^{2}=0.998\end{array}$ & $\begin{array}{c}100.00 \\
\pm \\
4.80\end{array}$ & $\begin{array}{c}76.80 \\
\pm \\
2.09\end{array}$ & $\begin{array}{c}338.60 \\
\pm \\
1.16\end{array}$ & $\begin{array}{c}200.30 \\
\pm \\
1.21\end{array}$ & 2000.00 \\
\hline $\begin{array}{l}\mathrm{Zn}(\mathrm{mg} / \mathrm{kg}) \\
\mathrm{R}^{2}=0.999\end{array}$ & $\begin{array}{c}28.40 \\
\pm \\
0.84\end{array}$ & $\begin{array}{c}69.10 \\
\pm \\
5.11\end{array}$ & $\begin{array}{c}211.20 \\
\pm \\
1.22\end{array}$ & $\begin{array}{c}37.70 \\
\pm \\
1.61\end{array}$ & 300.00 \\
\hline
\end{tabular}

Key: 707HEMSS $=707$ Housing Estate Maiduguri Soil Sample, GRADMSS $=$ G.R.A Damboa Road Maiduguri Soil Sample, NTESS = Nsukka Town Enugu Soil Sample, ATESS = Awgu TownEnugu Soil Sample, FAO/WHO STD = Food and Agricultural Organization/ World Health Organization Standard Maximum permissible limit in soil, ND = Not Detected.

Table 4: Mean concentration \pm STD of non-metal concentration in soil where Ocimumbasilicum and Ocimumgratissimumplants are planted.

\begin{tabular}{lcccc}
\hline Non metals & 707HEMSS & GRADMSS & NTESS & ATESS \\
\hline $\mathrm{P}(\mathrm{mg} / \mathrm{kg})$ & 694.89 & 643.00 & 1012.72 & 658.28 \\
& \pm & \pm & \pm & \pm \\
$\mathrm{S}(\mathrm{mg} / \mathrm{kg})$ & 5.18 & 22.73 & 22.73 & 33.24 \\
& 301.71 & 305.63 & 1684.88 & 1988.23 \\
& \pm & \pm & \pm & \pm \\
$\mathrm{N}(\mathrm{mg} / \mathrm{kg})$ & 16.62 & 11.08 & 55.41 & 75.87 \\
& 1.08 & 1.04 & 1.31 & 2.27 \\
& \pm & \pm & \pm & \pm \\
& 0.04 & 0.01 & 0.12 & 0.24
\end{tabular}

Key: 707HEMSS $=707$ Housing Estate Maiduguri Soil Sample, GRADMSS $=$ G.R.A Damboa Road Maiduguri Soil Sample, NTESS = Nsukka Town Enugu Soil Sample, ATESS = Awgu TownEnugu Soil Sample.

\section{Concentration of elements in leaves of Ocimumbasilicum and Ocimumgratissimum and soil}

Table 1 and 2 show the concentrations of $\mathrm{Ca}$, $\mathrm{Cu}, \mathrm{Co}, \mathrm{Fe}, \mathrm{Mn}, \mathrm{K}, \mathrm{Zn}, \mathrm{P}, \mathrm{S}$ and $\mathrm{N}$ in $O$. basilicum and $O$. gratissimum leaves. The results showed that Awgu town had the highest concentrations of $\mathrm{Ca}, \mathrm{Cu}, \mathrm{K}$, and $\mathrm{Zn}$ of $33024.60 \pm 477.19$ $\mathrm{mg} / \mathrm{kg}, 28.50 \pm 0.31 \mathrm{mg} / \mathrm{kg}, 2350.00 \pm 212.13$ $\mathrm{mg} / \mathrm{kg}$, and $98.80 \pm 1.10 \mathrm{mg} / \mathrm{kg}$ respectively in
O. gratissimum leaves, Nsukka town had the highest concentration of Fe of $2940.00 \pm 28.94$ $\mathrm{mg} / \mathrm{kg}$ in $O$. gratissimum leaves and G.R.A Damboa road had the highest concentration of $\mathrm{Mn}$ of $101.60 \pm 0.41 \mathrm{mg} / \mathrm{kg}$ in $O$. basilicum leaves. Co showed low concentrations in both $O$. gratissimum and 0 . basilicum leaves. The concentrations of all the metals showed lower value compared with the WHO/FAO and NAFDAC except $\mathrm{Fe}$ as illustrated in Table 1. 
BAJOPAS Volume 12 Number 1, June, 2019

The results for the non-metals showed that Nsukka town had the highest concentration of Phosphorus of $1530.00 \pm 72.14 \mathrm{mg} / \mathrm{kg}$ whileAwgu town had the highest concentration of sulphur of $5091.33 \pm 202.34 \mathrm{mg} / \mathrm{kg}$ in $O$. gratissimum leaves. However 707Housing Estate had the highest concentration of nitrogen of $34.05 \pm 1.06 \mathrm{mg} / \mathrm{kg}$ in 0 . basilicum leaves as illustrated in Table 2.

Tables 3 and 4 show the result for metals analyzed associated soil where the plants were grown. It was observed that 707Housing Estate had the highest concentrations of $\mathrm{Ca}$ and $\mathrm{K}$ of $7911.20 \pm 24.91 \mathrm{mg} / \mathrm{kg}$ and $490.00 \pm 29.69$ $\mathrm{mg} / \mathrm{kg}$ respectively in the soil, Nsukka town had the highest concentrations of $\mathrm{Cu}, \mathrm{Co}, \mathrm{Fe}, \mathrm{Mn}$ and $\mathrm{Zn}$ of $18.30 \pm 0.89 \mathrm{mg} / \mathrm{kg}, 2.40 \pm 0.34 \mathrm{mg} / \mathrm{kg}$, $3548.02 \pm 481.33 \mathrm{mg} / \mathrm{kg}, 338.60 \pm 1.16 \mathrm{mg} / \mathrm{kg}$ and $211.20 \pm 12.20 \mathrm{mg} / \mathrm{kg}$ respectively in the soil. All the soil samples showed low concentration of metals as compared with WHO/FAO standard except Fe at G.R.A Damboa road, Nsukka and Awgu town showed in Table 3. The result for the non-metals analyzed in soil showed that Awgu town had the highest concentrations of sulphur and nitrogen of $1988.23 \pm 75.87 \mathrm{mg} / \mathrm{kg}$ and $2.27 \pm 0.24 \mathrm{mg} / \mathrm{kg}$ respectively in the soil and Nsukka town had the highest concentration of phosphorus of 1012.72 $\pm 22.73 \mathrm{mg} / \mathrm{kg}$ in soil as illustrated in Table 4 .

The contamination of vegetables with minerals due to soil and atmospheric contamination poses a threat to its quality and safety. Dietary intake of elements also poses risk to animals and human health (Nazemiet al., 2012).

Awgu town had the highest concentration of $\mathrm{Ca}$ (33024.60 $\mathrm{mg} / \mathrm{kg}$ ) in 0 . gratissimum leave followed by G.R.A Damboa road and 707 Housing Estate (19160.00 and $17089.90 \mathrm{mg} / \mathrm{kg}$ ) in $O$. basilicumleaves respectively. Nsukka had the lowest concentration ( $14096.00 \mathrm{mg} / \mathrm{kg}$ ) of $\mathrm{Ca}$ in 0 . gratissimum leaves. The WHO/FAO agency had not provided the standard of $\mathrm{Ca}$ in vegetable likewise NAFDAC as shown in Table 1. High concentration of $\mathrm{Ca}$ in $\mathrm{O}$. basilicum leaves had been reported by Daniel et al. (2011) which was agreed with reference to the result obtained. For 0 . gratissimum leaves, however, concentrations reported by Idriset al. (2011) and Asaoluet al. (2012) were very low compared to what we obtained. In soil, 707Housing Estate had the highest concentration of $\mathrm{Ca}$ (7911.20 $\mathrm{mg} / \mathrm{kg}$ ) followed by G.R.A Damboa Road and Awgu town of (4568.60 and $2779.00 \mathrm{mg} / \mathrm{kg}$ ) respectively. Nsukka town had the lowest concentration $(1503.50 \mathrm{mg} / \mathrm{kg})$. The WHO/FAO had no standard for $\mathrm{Ca}$ in soil as well shown in Table 3.
Awgu town having the highest concentration of $\mathrm{Cu}(28.50 \mathrm{mg} / \mathrm{kg})$ followed by Nsukka town $(18.30 \mathrm{mg} / \mathrm{kg}$ ) in $O$. gratissimum leaves and G.R.A Damboa road $(12.30 \mathrm{mg} / \mathrm{kg})$ in $O$. basilicumleaves. 707Housing Estate had the lowest concentration $(5.10 \mathrm{mg} / \mathrm{kg})$ of $\mathrm{Cu}$ in $O$. basilicum leaves. Both leaves species showed low concentration of $\mathrm{Cu}$ when compared with WHO/FAO and NAFDAC standards in vegetable and foodrespectively shown in Table 1 . Low concentration of $\mathrm{Cu}$ in $\mathrm{O}$. basilicum leaves was reported by Agunbiadeet al. (2015) and in $O$. gratissimum leaves as reported by Idriset al. (2011) and Asaoluet al. (2012). The results agreed with the results obtained in the current study. In soil sample from Nsukka town had the highest concentration of $\mathrm{Cu}(18.30 \mathrm{mg} / \mathrm{kg})$ followed by 707 Housing Estate $(9.30 \mathrm{mg} / \mathrm{kg}$ ) and G.R.A Damboa road $(7.00 \mathrm{mg} / \mathrm{kg}$ ) in soil. Awgu town had the lowest concentration (3.40 $\mathrm{mg} / \mathrm{kg}$ ) in soil samples. The soil samples showed low concentrations of $\mathrm{Cu}$ when compared with WHO/FAO standard in soil as shown in Table 3.

Cobalt was not detected in any of the leaf samples analyzed shown in Table 1 . In soil samples however, only Nsukka samples confirmed Co at a concentration of $2.40 \mathrm{mg} / \mathrm{kg}$. The WHO/FAO standard shows that the soil was not contaminated with Co as illustrated in Table 3.

Nsukka town had the highest concentration of Fe $(2940.00 \mathrm{mg} / \mathrm{kg})$ in 0 . grtissimum leaves followed by G.R.A Damboa road (1797.30 $\mathrm{mg} / \mathrm{kg}$ ) in $O$. basilicum leaves and Awgu town $(973.70 \mathrm{mg} / \mathrm{kg})$ in $O$. grtissimum leaves. 707Housing Estate had the lowest concentration of $\mathrm{Fe}(526.00 \mathrm{mg} / \mathrm{kg})$ in 0 . basilicum leaves. Both leaves species were above the permitted limit concentration of $\mathrm{Fe}$ when compared with WHO/FAO and NAFDAC standardsin vegetables andfood respectively as shown in Table 1 . Low concentration of $\mathrm{Fe}$ in $\mathrm{O}$. basilicumleaves was reported by Agunbiadeet al. (2015); also low concentration of $\mathrm{Fe}$ in 0 . gratissimum leaves was reported by Idriset al. (2011) and Asaoluet al. (2012). These results disagreed with our results. In soil,Nsukka town had the highest concentration of $\mathrm{Fe}(35480.20 \mathrm{mg} / \mathrm{kg})$ followed by Awgu town (22016.70 mg/kg) and G.R.A Damboa road $(5745.00 \mathrm{mg} / \mathrm{kg})$. 707Housing Estate had the lowest concentration of $\mathrm{Fe}$ (2866.10 mg/kg). Soil at Awgu town, Nsuka town and G.R.A Damboa road were above the permitted limit concentration of $\mathrm{Fe}$ when compared to WHO/FAO standard in soil Therefore, the soil samples had high content of Fe at those sampling sites shown in Table 3. 
BAJOPAS Volume 12 Number 1, June, 2019

Ocimumgratissimum leaves had the highest concentration of $\mathrm{K}(2350.00 \mathrm{mg} / \mathrm{kg})$ atAwgu town followed by G.R.A Damboa road (1795.00 $\mathrm{mg} / \mathrm{kg}$ ) in 0 . basilicum leaves and 707 Housing Estate $(1497.50 \mathrm{mg} / \mathrm{kg})$ in $O$. basilicum leaves. Nsukka town had the lowest concentration of $(1400.00 \mathrm{mg} / \mathrm{kg}$ ) in 0 . gratissimum leaves. The WHO/FAO and NAFDAC standard of $\mathrm{K}$ were not available for vegetables and food respectively as shown in Table 1 . High concentration of $\mathrm{K}$ in $O$. basilicumleaves was reported by Daniel et al. (2011) and high concentration of $O$. gratissimum leaves was reported by idriset al. (2011). These agreed with our result. In soil, 707Housing Estate had the highest concentration of $\mathrm{K}$ (4900.00 mg/kg) followed by G.R.A Damboa Road (3407.50 mg/kg) and Nsukka (2370.00 $\mathrm{mg} / \mathrm{kg}$ ). Awgu town had the lowest concentration $(610.00 \mathrm{mg} / \mathrm{kg})$. The WHO/FAO standard for $\mathrm{K}$ in soil was not available for soil as shown in Table 3.

Ocimumbasilicum leaves found at G.R.A Damboa road had the highest concentration of $\mathrm{Mn}$ $(101.60 \mathrm{mg} / \mathrm{kg})$ followed by Nsukka town $(84.80$ $\mathrm{mg} / \mathrm{kg}$ ) in 0 . gratissimum leaves and Awgu town $(71.10 \mathrm{mg} / \mathrm{kg})$ in 0 . gratissimum leaves. 707Housing Estate had the lowest concentration $(54.00 \mathrm{mg} / \mathrm{kg})$ of $\mathrm{Mn}$ in $O$. basilicum leaves. The WHO/FAO and NAFDAC standard of Mn show that the entire leaves sample were lower than the permissible limits as shown in Table 1. Low concentration of 0 . gratissimum was reported by Idris et al. (2011) and Asaolu et al. (2012). In soil, Nsukka town had the highest concentration (338.60 mg/kg) in soil followed by Awgu town $(200.30 \mathrm{mg} / \mathrm{kg})$ and 707Housing Estate (100.00 $\mathrm{mg} / \mathrm{kg}$ ). G.R.A Damboa road had the lowest concentration of $\mathrm{Mn}(76.80 \mathrm{mg} / \mathrm{kg})$. The WHO/FAO standard of $\mathrm{Mn}$ in soil show that all soil samples were lower than the permissible limit as shown in Table 3.

Ocimumgratissimum leaves found at Awgu town had the highest concentration of $\mathrm{Zn}(98.80$ $\mathrm{mg} / \mathrm{kg}$ ) followed by Nsukka town $(88.20 \mathrm{mg} / \mathrm{kg}$ ) in O. gratissimum and G.R.A Damboa road $(59.10 \mathrm{mg} / \mathrm{kg}$ ) in 0 . basilicum. 707Housing Estate had the lowest concentration of Zn (37.30 $\mathrm{mg} / \mathrm{kg}$ ) in $O$. basilicum leaves. The WHO/FAO and NAFDAC Standards of $\mathrm{Zn}$ show that the entire samples were lower than the permissible limit in vegetable and food respectivelyas illustrated in Table 1. High concentration of $\mathrm{Zn}$ in $O$. basilicum leaves was reported by Agunbiade et al. (2015); also high concentration in 0 . gratissimum leaves was reported by Idriset al. (2011) and Asaolu et al. (2012). In soil,Nsukka town had the highest concentration of $\mathrm{Zn}$
( $211.20 \mathrm{mg} / \mathrm{kg}$ ) followed by G.R.A Damboa road $(69.10 \mathrm{mg} / \mathrm{kg})$ and Awgu town $(37.70 \mathrm{mg} / \mathrm{kg})$ in soil. 707Housing Estate had the lowest concentration of $\mathrm{Zn}(28.40 \mathrm{mg} / \mathrm{kg})$ in soil. The WHO/FAO standard show that the entire soil samples were below the permissible limit in soil as shown in Table 3.

Nsukka town had the highest concentration of $P$ $(4123.23 \mathrm{mg} / \mathrm{kg})$ in $O$. gratissimum leaves followed by 707 Housing Estate $(3580.66 \mathrm{mg} / \mathrm{kg}$ ) in $O$. basilicum leaves and G.R.A Damboa road (3219.02 mg/kg) in O. basilicum leaves. Awgu town had the lowest concentration (1530.49 $\mathrm{mg} / \mathrm{kg}$ ) in 0. gratissimum leaves shown in Table 2 . Low concentration of $P$ in 0 . gratissimum was reported by Idris et al. (2011) and Asaoluet al. (2012); high concentration of $P$ in $O$. basilicum leaves was reported by Agunbiade et al. (2015). In soil, Nsukka had the highest concentration of P (1012.72 $\mathrm{mg} / \mathrm{kg}$ ) followed by 707 Housing Estate $(694.89 \mathrm{mg} / \mathrm{kg}$ ) and G.R.A Damdoa road $(643.00 \mathrm{mg} / \mathrm{kg})$ in 0 . basilicum leaves. Awgu town had the lowest concentration of $\mathrm{P}(658.28$ $\mathrm{mg} / \mathrm{kg}$ ) as shown in Table 4 . The concentration of phosphorus in leaves at Awgu town was due to the high concentration of phosphorus in the soil.

Ocimumgratissimum found at Awgu town had the highest concentration of sulphur (5091.33 $\mathrm{mg} / \mathrm{kg}$ ) followed by Nsukka town (3467.72 $\mathrm{mg} / \mathrm{kg}$ ) in 0 . gratissimum leaves and 707Housing Estate $(2351.00 \mathrm{mg} / \mathrm{kg})$ in $O$. basilicum leaves. G.R.A Damboa road had the lowest concentration of $S(2057.15 \mathrm{mg} / \mathrm{kg})$ in $O$. basilicum leaves as shown in Table 2 . In soil,Awgu town had the highest concentration (1988.23 $\mathrm{mg} / \mathrm{kg}$ ) followed by Nsukka town (1684.88 $\mathrm{mg} / \mathrm{kg}$ ) and G.R.A Damdoa road (305.63 mg/kg). 707Housing Estate had the lowest concentration of $\mathrm{S}(301.71 \mathrm{mg} / \mathrm{kg})$ as shown in Table 4. The high concentration of sulphur in the leaves at Awgu town might be due to the high concentration of sulphur in the soil.

Ocimumbasilicum eaves found at 707 Housing Estate had the highest concentration of Nitrogen ( $34.05 \mathrm{mg} / \mathrm{kg}$ ) in 0 . basilicum leaves followed by Nsukka town of $29.10 \mathrm{mg} / \mathrm{kg}$ in 0 . gratissimum leaves and Awgu town (12.42 mg/kg) in 0 . gratissimum leaves. G.R.A Damboa road had the lowest concentration of $\mathrm{N}(6.75 \mathrm{mg} / \mathrm{kg})$ in $O$. basilicum leaves as shown in Table 2. In soil,Awgu town had the highest concentration of $\mathrm{N}(2.27 \mathrm{mg} / \mathrm{kg})$ followed by Nsukka town (1.31 $\mathrm{mg} / \mathrm{kg}$ ) and 707Housing Estate (1.08 mg/kg). G.R.A Damboa road had the lowest concentration $(1.04 \mathrm{mg} / \mathrm{kg})$ as shown in Table 4. 
BAJOPAS Volume 12 Number 1, June, 2019

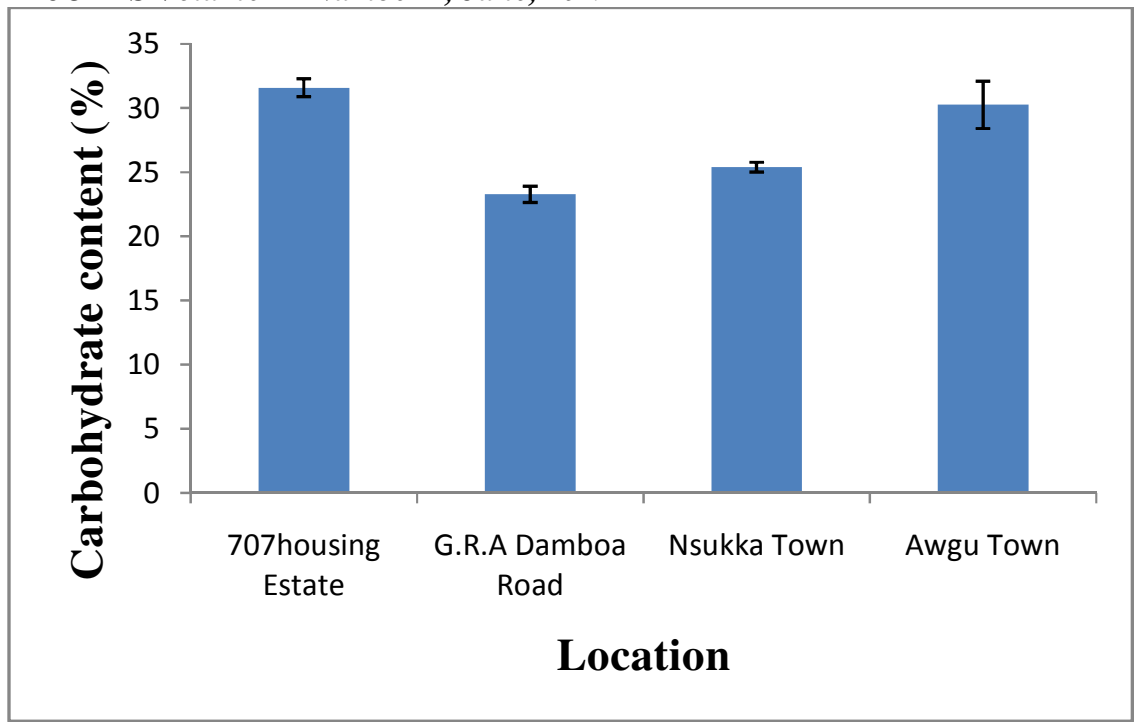

Figure 3: Percentage of carbohydrate in leaves of Ocimumbasilicum obtained from 707housing Estate and G.R.A Damboa road and leaves of Ocimumgratissimum obtained from Nsukka town and Awgu town.

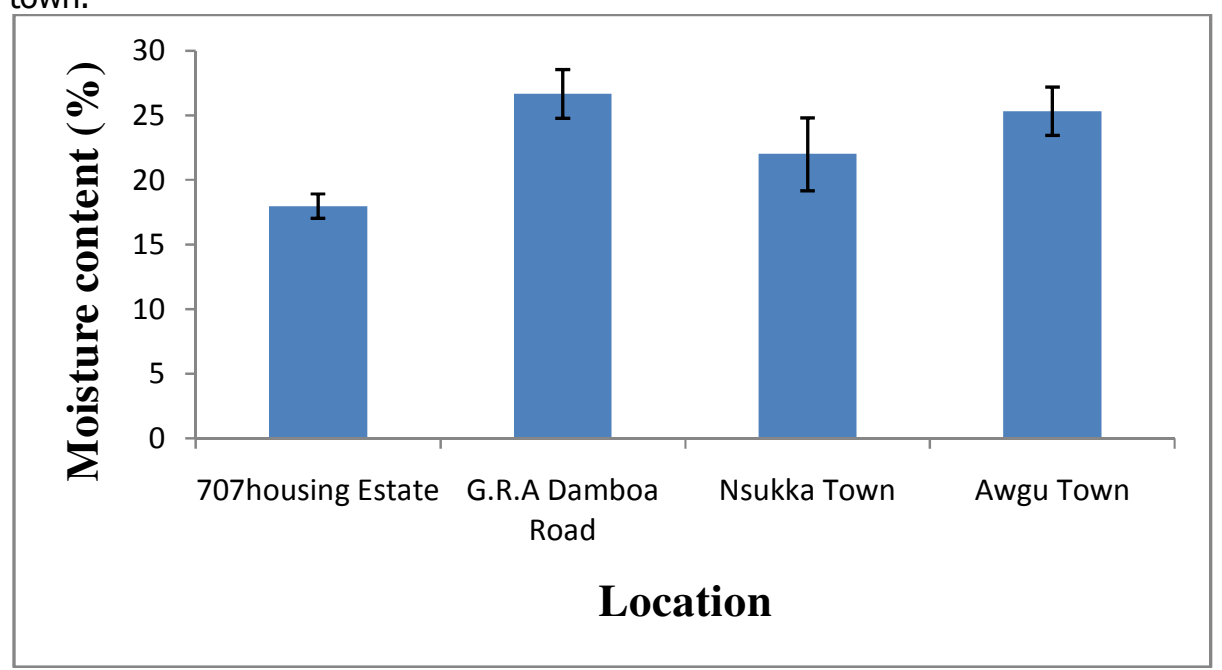

Figure 4: Percentage of moisture content in leaves of Ocimumbasilicum obtained from 707Housing Estate and G.R.A Damboa road and leaves of Ocimumgratissimum obtained from Nsukka town and Awgu town.

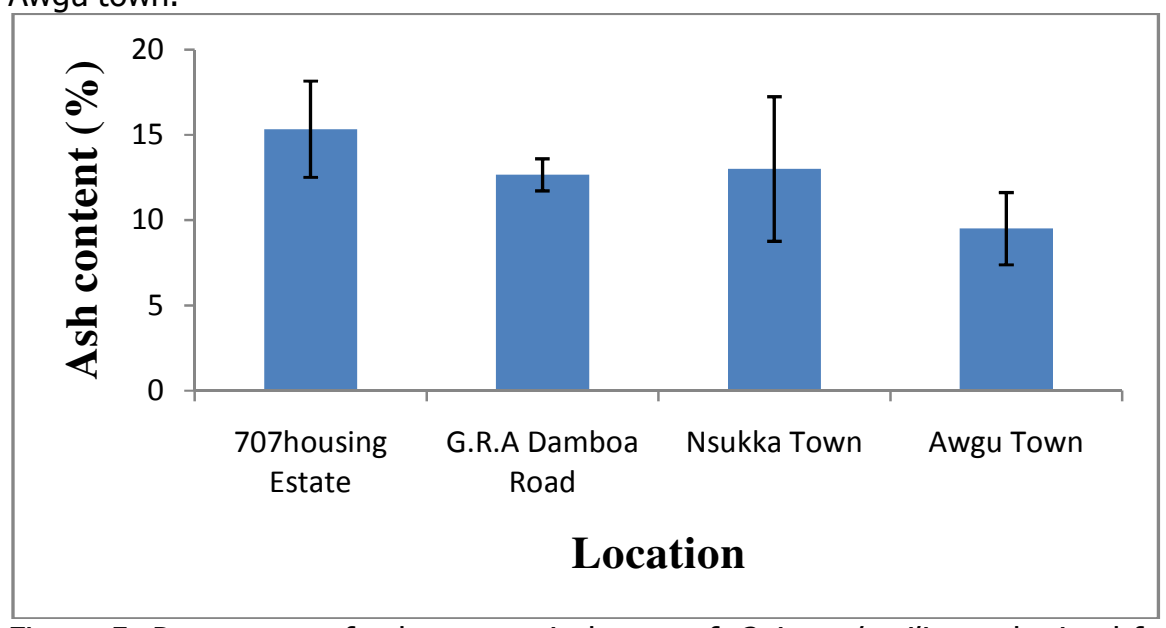

Figure 5: Percentage of ash content in leaves of Ocimumbasilicum obtained from 707Housing Estate and G.R.A Damboa road and leaves of Ocimumgratissimum obtained from Nsukka town and Awgu town. 


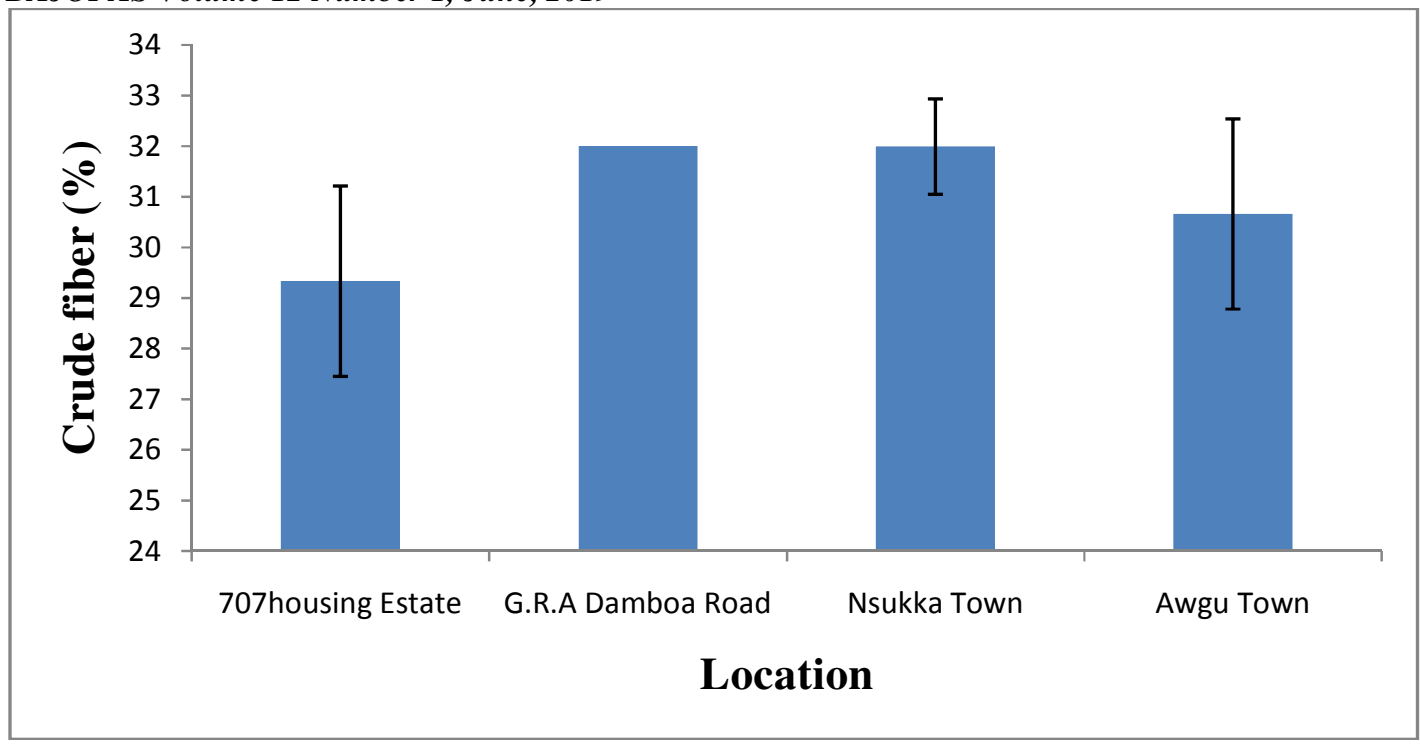

Figure 6: Percentage of crude fiber in leaves of Ocimumbasilicum obtained from 707Housing Estate and G.R.A Damboa road and leaves of Ocimumgratissimum obtained from Nsukka town and Awgu town.

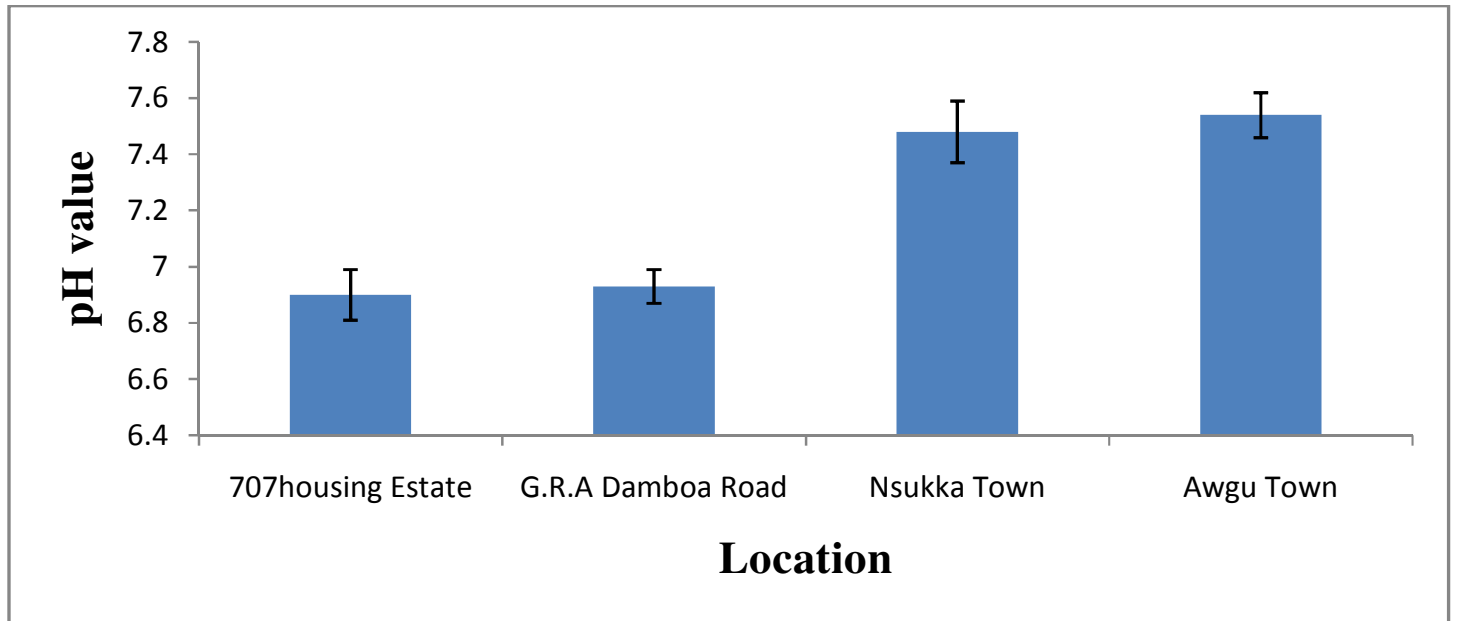

Figure 7: $\mathrm{pH}$ value in leaves of Ocimumbasilicum obtained from 707Housing Estate and G.R.A Damboa road and leaves of Ocimumgratissimum obtained from Nsukka town and Awgu town.

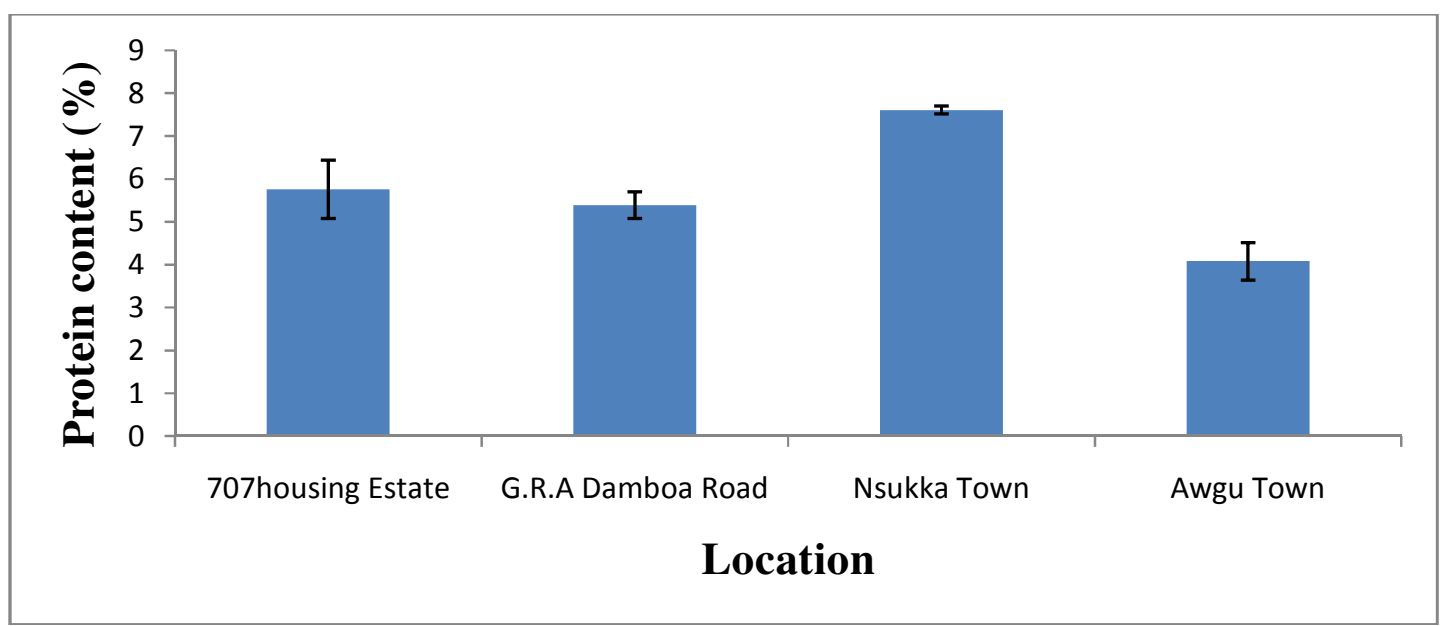

Figure 8: Percentage of protein content in leaves of Ocimumbasilicum obtained from 707Housing Estate and G.R.A Damboa road and leaves of Ocimumgratissimum obtained from Nsukka town and Awgu town. 


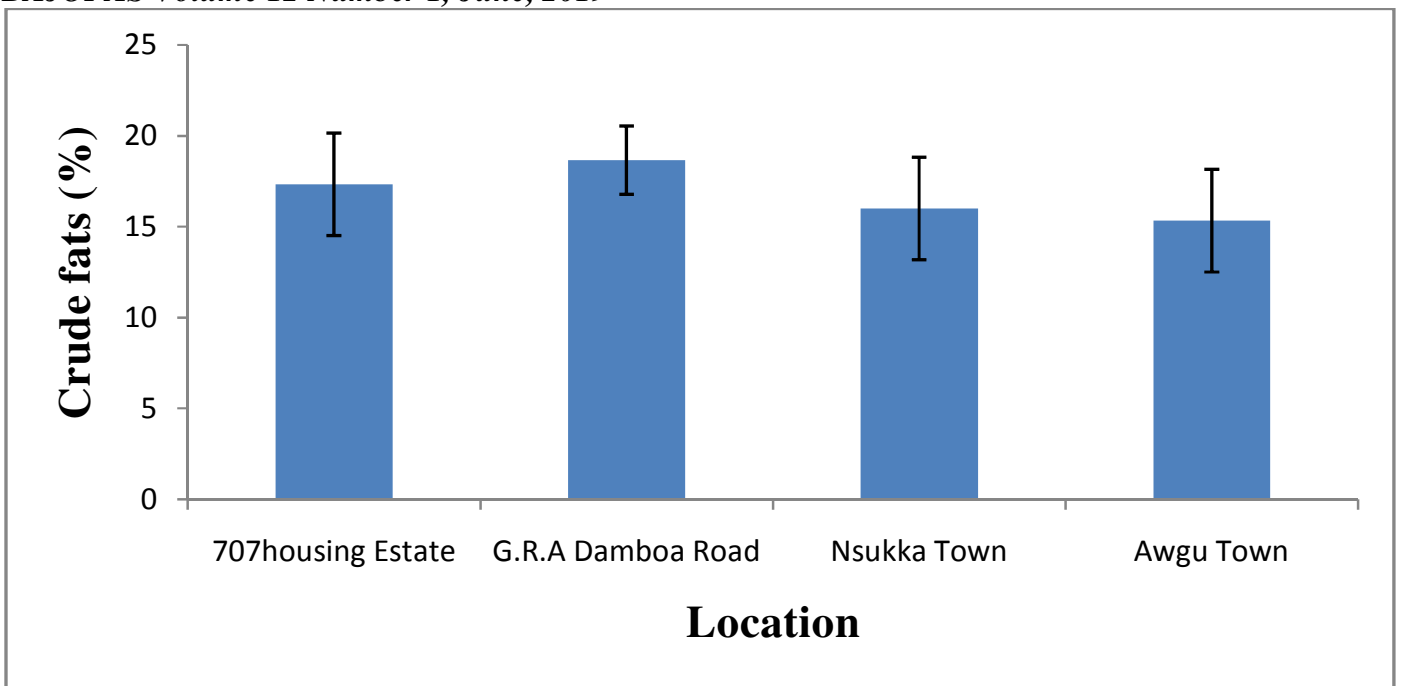

Figure 9: Percentage of crude fats in leaves of Ocimumbasilicum obtained from 707Housing Estate and G.R.A Damboa road and leaves of Ocimumgratissimum obtained from Nsukka town and Awgu town.

\section{Proximate contents of plant leaves of Ocimumbasilicum and Ocimumgratissimum}

Figure 3 to 9 showed the mean percentage of proximate contents of Carbohydrate, moisture, ash, crude fiber, $\mathrm{pH}$ value, protein and fats in Ocimumbasilicum and Ocimumgratissimum leaves.The result showed that 707 Housing Estate has maximum percentage of carbohydrate and ash content of $31.58 \pm 0.69 \%$ and $15.33 \pm 2.82 \%$ respectively as illustrated in Figure 3 and 5, G.R.A Damboa road has maximum percentage of moisture, crude fiber and crude fats content of $26.66 \pm 1.88,32.00 \%$ $\pm 0.00 \%$ and $18.66 \pm 1.88 \%$ respectively asillustrated in Figure 4, 6 and 9 in 0 . basilicum leaves. Nsukka town has maximum percentage of protein content of $7.61 \pm 0.09 \%$ in $O$. gratissimum leaves illustrated in Figure 8. 707Housing Estate and G.R.A Damdoa road has a $\mathrm{pH}$ of $6.90 \pm 0.09$ and $6.93 \pm 0.06$ respectively in 0 . basilicum leaves which are slightly acidic and Nsukka town and Awgu town has a pH of $7.48 \pm 0.11$ and $7.54 \pm 0.08$ respectively in 0 . gratissimum leaves which are slightly basic as illustrated in Figure 7.

Scent leaf contains nutritional constituents such as fats, protein, carbohydrates etc. (Nwankwo et al., 2014). Vegetables constitute an important part of the human diet since they contain carbohydrates, proteins, vitamins, minerals as well as trace elements (Nazemi, 2012). High percentage contents of carbohydrate and protein were obtained in this work, also low percentage contents of ash and crude fiber were also obtained. High percentage contents of carbohydrate and protein and low percentage contents of ash, fats and fiber were reported in 0 . gratissimum leaves by Nwankwoet al., Asaoluet al. and Idriset al. (2014, 2012 and 2011) respectively.

Ocimumbasilicum leaves at 707 Housing Estate had the highest percentage ofcarbohydrate contents $(31.58 \%)$ follow by Awgu town $(30.25 \%)$ in 0. gratissimum leaves and Nsukka town $(25 \%)$ in O. gratissimum leaves. G.R.A Damboa road had the lowest percentage of carbohydrate content $(23.28 \%)$ in 0 . basilicum leaves as shown in Figure 3.

Similarly, Ocimumbasilicum leaves at G.R.A Damboa road had the highest percentage of moisture contents $(26.66 \%)$ follow by Awgu town $(25.33 \%)$ in 0 . gratissimum leaves and Nsukka town $(22.00 \%)$ in 0 . gratissimum leaves. 707 Housing Estate had the lowest percentage $(17.99 \%)$ in $O$. basilicum leaves as shown in Figure 4.

Also Ocimumbasilicum leaves at 707 Housing Estate had the highest percentage of ash content $(15.33 \%)$ follow by Nsukka town $(13.00 \%)$ in 0 . gratissimum leaves and G.R.A Damdoa road (12.66\%) in O. basilicumleaves. Awgu town had the lowest percentage of ash content $(9.50 \%)$ in 0 . gratissimum leaves as shown in Figure 5.

Furthermore, G.R.A Damboa road had the highest percentage of crude fiber content $(32.00 \%)$ in 0 . basilicumleaves follow by Nsukka town $(31.99 \%)$ in 0 . gratissimum leaves and Awgu town $(30.66 \%)$ in 0 . gratissimum leaves. 707Housing Estate had the lowest percentage of crude fiber $(29.33 \%)$ in 0 . basilicum leaves as shown in Figure 6. 
BAJOPAS Volume 12 Number 1, June, 2019

The $\mathrm{pH}$ value in $O$. basilicum leaves found at 707Housing Estate (6.90) and G.R.A Damboa road (6.93) were slightly acidic, while $\mathrm{pH}$ values in 0 . gratissimum leaves found at Nsukka town (7.48) and Awgu town (7.54) were slightly basic as shown in Figure 7.Slightly acidic was obtained in 0 . basilicum eaves as reported by Agunbaide et al. (2015).

Nsukka town had the highest percentage of crude protein content $(7.61 \%)$ in 0 . gratissimum leaves followed by 707 Housing Estate (5.76\%) in $O$. basilicumleaves and G.R.A Damboa road (5.39\%). Awgu town had the lowest percentage of proteins $(4.08 \%)$ in 0 . basilicumleaves as shown in Figure 8.

Ocimumbasilicum leaves at G.R.A Damboa road had the highest percentage of crude fats content (18.66\%) follow by 707 Housing Estate $(17.33 \%)$ in $O$ basilicumleaves and Nsukkatown (16.00\%) in 0 . gratissimum leaves. Awgu town had the lowest percentage of crude fats $(15.33 \%)$ in 0 . gratissimum laves as shown in Figure 9.

Table 5: Significant difference of nutritional contents of 0 . basilicum, 0 . gratissimum leaves and soil samples found in the four sampling locations against their concentrations.

\begin{tabular}{lc}
\hline Nutritional contents & $p$ value \\
\hline Elemental composition for leaves & 0.956 \\
Elemental composition for soil & 0.505 \\
Proximate contents of leaves & 1.000 \\
\hline
\end{tabular}

pvalue at $\leq 0.05$ significant

\section{Statistical Analysis of data of Elemental analysis and proximate analysis of Ocimumbasilicum and Ocimumgratissimumplant leaves with soil.}

Analysisof variance (ANOVA) was explored for nutritional contents (elemental compositions and proximate contents) for 0 . basilicum and 0 . gratissimum leaves samples and soil found in the four sampling locations against their concentrations. The following significant of the nutritional contents was obtained at $p \leq 0.05$ shown in Table 5.

All recorded $\mathrm{p}$ values there were greater than 0.05, indicating lack of significant difference between the compared groups based on difference of species and geographical variation.

\section{CONCLUSION}

The nutritional contents of leaves of 0 . basilicumand $O$. gratissimum showed that $O$. gratissimum had higher concentrations of $\mathrm{Ca}$, $\mathrm{Cu}, \mathrm{K}, \mathrm{Zn}, \mathrm{Fe}, \mathrm{S}$ and $\mathrm{P}$ while O.basilicumhad higher concentration of $\mathrm{Mn}$ and $\mathrm{N}$ in the essential element concentration. However, the soil where both leaves were planted were not contaminated. Fe concentration in both leaves was higher than WHO/FAO standard in vegetable and soil and NAFDAC standard for food. 0 . basilicumhad higher contents of carbohydrate, ash, moisture, fiber and fat

\section{REFERENCE}

Agunbiade, S. O., Ojezele, M. O., and Alao, O. O. (2015). Evaluation of the Nutritional, Phytochemical Compositions and Likely Medicinal Benefits of Vernomiaamygdalina , Talinumtriangulare

and content and was slightly acidic while $O$. gratissimum had higher protein content and was slightly basic. Both leaves showed good nutrition content with respect to the elemental composition, and proximate contents. Statistically both leaves showed no differences in all the content checked in respect of the antioxidant properties and nutritional contents.

\section{RECOMMENDATION}

Both leaves of $O$. basilicumand $O$. gratissimum have good nutritional values. Therefore, applying scent (Ocimum)leavesin daily meal will help in building and boosting the body system; also the consumption of both leaves have to be regulated due to the high content of iron.

\section{ACKNOWLEDGEMENT}

I wish to thank the lab technicians, Dr. Bashir, Muti-user Lab, MrAlhamdu and Colic of Chemistry Department, Ahmadu Bello University for their support, encouragement and assistance in carrying out the analysis.

\section{Conflict of interest}

There was no conflict of interest exist among the authors regarding the publication of this article.

\section{Contribution of authors}

AnjiliMalgwi Ezekiel design and carryout the research work, NuhuAbdulkadir Abdulmumin and UbaSani supervised the research work.

Ocimumbasilicum Leafy-Vegetables, 9(3): 151-155.

AOAC, (1990).Official methods of analysis.15th edition.Association of Official Analytical Chemists, Washington DC, USA.

Asaolu, S. S., Adefemi, O. S., Oyakilome, I. G., Ajibulu, K. E., \&Asaolu, M. F. (2012). Proximate and Mineral Composition of 
BAJOPAS Volume 12 Number 1, June, 2019 Nigerian Leafy Vegetables, 1(3), 214218. http://doi.org/10.5539/jfr.v1n3p214

Bolanle, Ajayi Olubunmi, Akomolafe Seun Funmilola, and Adefioye Adedayo (2014). Proximate Analysis, Mineral Contents, Amino Acid Composition, AntiNutrients and Phytochemical Screening of Brachystegia EurycomaHaems and Pipper Guineense Schum and Thonn.American Journal of Food and Nutrition, 2(1):11-17.

Clementson, Jan (2014). Macronutrients vs Micronutrients Retrieved (Pdf) $20^{\text {th }}$ june 2014 from http://borderharriers.co.uk/app/webroo t/upload/File/Nutrition/Nutrition\%204\% 20Jun\%2014

Daniel, V.N., Daniang I. E., and Nimyel N.D. (2011). Phytochemical analysis and mineral elements composition of Ocimumbasilicum obtained in Jos metropolis plateau state, Nigeria. International Journal of Engineering and Technology (IJET-IJENS).11(6): 135-137.

Effrain, I. O., Salami, H. A. and T. S. (2000). The effect of aqueous leaf extract of Ocimumgratissimum on Haematologcal and Biological parameters in Rabbits. African Journal of Biomedical Research,1; 175-179

Gad,Nadia , Aziz Eman E., BekbayevaLyazzat K. and SurifMisni., (2013). Role of Cobalt in Sweet Basil (Ocimumbasilicum L.)Plants B. Endogenous Hormones, Chemical and Nutritional Contents. American-Eurasian Journal of Agricultural and Environmental Science, 13(1): 16-21,

Gul, shumaila and Mahpara Safdar., (2009). Proximate composition and mineral Analysis of Cinnamom. Pakistan Journal of Nutrition 8(9)1456-1460.

Idris S., Iyaka Y.A., Ndamitso M. M. and Paiko Y.B., (2011). Nutritional Composition of the Leaves and Stems of Ocimum Gratissimum. Journal of Emerging Trends in Engineering and Applied Sciences (JETEAS)2 (5): 801-805.

Katarzyna, Dzida, (2010). Nutrients contents in sweet basil (ocimumbasilicum l.) Herb depending on calcium carbonate dose and cultivar Sci, A., \&Cultus, H. 9(4), 143-151.

Nazemi, Lyly, Nazmara Shahrokh, Eshraghyan Mohammad Reza, NasseriSimin, Djafarian Kurosh, Yunesian Masoud, Sereshti Hassan, Moameni Aziz and ShahtaheriSeyed Jamaleddin . (2012). Selenium status in soil, water and essential crops of Iran. Iranian Journal of Environmental Health Science \& Engineering9(11)https://doi.org/10.118 6/1735-2746-9-11

Nwankwo, Chibuzo. S., Ebenezer, Ike. A., Ikpeama, Ahamefula. I., Asuzu, Francess. O., (2014). The nutritional and anti - nutritional values of two culinary herbs - uziza leaf (Piper guineense) and scent leaf (Ocimumgratissium) popularly used in Nigeria. International Journal of Scientific \& Engineering Research, Volume 5, Issue 12, p1160-1163 ISSN 2229-5518.http://www.ijser.org/

Owoso, O. \&Ogunmoyela, O. A. 2001.Proximate Constituents of Food. In:Chemical Analysis of Foods- an outline. Concept Publishers Limited, Lagos Nigeria.

Saeid, Nazemi, (2012). Concentration of Heavy Metal in Edible Vegetables Widely Consumed in Shahroud, the North East of Iran J. Appl. Environ. Biol. Sci.2(8)386-391, ISSN 2090-4274 www.textroad.com

Udo, E.J and Ogunwele D.A (1986) Laboratory Manual for Analysis.In Soil, Plants and Water Analysis 3rd Edition. Ilorin, University of Ilorin, Kwara State Nigeria P 131-152. 